\title{
PENGARUH PENILAIAN KINERJA, PENGALAMAN KERJA, DAN PELATIHAN TERHADAP PENGEMBANGAN KARIR KARYAWAN
}

\author{
I Kadek Suadnyana ${ }^{1}$ \\ I Wayan Gede Supartha ${ }^{2}$ \\ ${ }^{1,2}$ Fakultas Ekonomi dan Bisnis Universitas Udayana, Bali, Indonesia \\ e-mail: suadnyana11ono@gmail.com
}

\begin{abstract}
ABSTRAK
Pengembangan karir adalah proses peningkatan kemampuan, jabatan, maupun tanggung jawab . Dalam pengembangan karir karyawan perusahaan perlu memberikan dukungan baik dukungan dalam informasi, pelatihan maupun kesempatan. Tujuan penelitian ini adalah untuk mengetahui pengaruh penilaian kinerja, pengalaman kerja, dan pelatihan terhadap pengembangan karir. Penelitian ini dilakukan di Bali Masari Villas and SPA. Jumlah sampel sebanyak 47 orang dengan menggunakan metode stratified random sampling. Pengumpulan data dilakukan melalui wawancara dan kuisioner. Teknik analisis yang digunakan adalah analisis regresi linear berganda. Hasil analisis dalam penelitian ini menemukan bahwa penilaian kinerja berpengaruh positif dan signifikan terhadap pengembangan karir. Pengalaman kerja berpengaruh positif dan signifikan terhadap pengembangan karir. Pelatihan berpengaruh positif dan signifikan terhadap pengembangan karir
\end{abstract}

Kata kunci : penilaian kinerja, pengalaman kerja, pelatihan, pengembangan kari

\begin{abstract}
Career development is the process of capacity building, position, and responsibility. In employee career development the company needs to provide support both in support of information, training and opportunity. The purpose of this study is to determine the effect of performance appraisal, work experience, and training on career development. This research was conducted in Bali Masari Villas and SPA. The number of samples was 47 people using stratified random sampling method. Data collection was done through interviews and questionnaires. The analysis technique used is multiple linear regression analysis. The results of the analysis in this study found that the performance appraisal has a positive and significant impact on career development. Work experience has a positive and significant impact on career development. Training has a positive and significant impact on career development.
\end{abstract}

Keywords :performance appraisal, work experience, training, career development 


\section{PENDAHULUAN}

Pengembangan karir adalah suatu proses dalam hidup seseorang yang nantinya akan mampu membuat orang tersebut lebih matang, lebih mampu memanfaatkan potensi dirinya sehingga mencapai karir yang sesuai dengan dirinya (Dessler, 2009). Setiap orang tentu menginginkan perkembangan atau suatu peningkatan dalam karir mereka. Walaupun beberapa orang menganggap perkembangan karir seseorang banyak dipengaruhi oleh keberuntungan, namun dalam pengembangan karir tetap dibutuhkan perencanaan yang tepat serta pemanfaatan peluang yang baik sehingga karir dapat berkembang sesuai dengan keinginan. Ini menyoroti bahwa pada periode yang berbeda selama kehidupan seseorang, prioritas yang berbeda datang ke permukaan, yang mungkin memerlukan pilihan pengembangan karir yang berbeda, seperti kemampuan untuk mengambil jeda karir, mengurangi jam kerja atau untuk meningkatkan tanggung jawab, tergantung pada keadaan pribadi individu dan Peluang dalam organisasi (Crowley-Henry, 2012).Terdapat beberapa hal yang mampu mempengaruhi pengembangan karir seseorang diantaranya pengunduran diri, kesetiaan terhadap organisasi, pengalaman, prestasi kerja, pembimbing dan sponsor, pengenalan, bawahan yang mempunyai peran kunci, jaringan kerja (Rivai, 2011:274-279).

Dalam sumber daya manusia pengembangan karir adalah salah satu hal yang tidak dapat diabaikan (Sari dan Sinulingga, 2011). Salah satu definisi pengembangan karir adalah mampu meningkatnya kemampuan kerja seorang karyawan (individu) guna dapat mencapai pengembangan karir sesuai minat dan bakat (Candra, 2016).Kinerja karyawan berhubungan dengan pengembangan karir, 
hal ini karena pengembangan karir adalah salah satu pendekatan resmi yang dapat digunakan perusahaan dengan maksud menjaga sumber daya manusia unggul yang terdapat di perusahaan (Kaseger, 2013). Karyawan yang ingin melakukan pengembangkan karir perlu memperhatikan penilaian kinerja, dan melihat apa yang unggul dalam dirinya. Sehingga perencanaan pengembangan karir dari tiap-tiap karyawan bisa saja berbeda-beda. Penilaian kinerja seharusnya dapat memberikan penjelasan serta informasi pada karyawan tentang bagaimana kinerja mereka selama ini. Penilaian kinerja juga harus dijadikan dasar dalam penentuan pengembangan karir karyawan oleh perusahaan.

Perusahaan harus memiliki evaluasi guna memberikan informasi tentang bagaimana kinerja karyawan di perusahaan tersebut. Perusahaan harus melatih manajer mereka tentang bagaimana melakukan penilaian kinerja dan manajer harus mengetahui bagaimana menetapkan tujuan dan sasaran yang tepat pada awal tahun kalender atau tahun evaluasi (Steven et al., 2011). Penilaian kinerja dapat digunakan secara lebih luas sehingga bisa menjadi alat utama bagi perusahaan dalam pengembangan sumber daya manusianya (Prowse and Prowse, 2009). Namun jika penilaian kinerja dilakukan secara tidak baik justru akan menjadi boomerang bagi perusahaan, karena akan mengakibatkan penurunan produktivitas kerja karyawan. Dukungan organisasi terhadap pengembangan karir merupakan salah satu halterpenting dalam memaksimalkan penilaian kinerja di perusahaan Saleem dan Amin (2013).

Penilaian kinerja tidaklah satu-satunya hal yang perlu diperhatikan ketika ingin melakukan pengembangan karir karyawan, masih ada pengalaman kerja serta 
pelatihan.Dokko et al. (2008) menyatakan pengalaman dan kinerja memiliki keterikatan terhadap pengembangan karir lewat pengetahuan dan keterampilan. Tidak diragukan lagi, mendapatkan pengalaman selama masa studi memungkinkan siswa meningkatkan pemahaman mereka tentang tempat kerja (Wang et al., 2014). On the job training adalah salah satu cara bagaimana perusahaan memberikan pengalaman bagi karyawannya. Mahony et al. (2012) menyatakan jika nilai yang diperoleh dari pengalaman kerja semakin besar maka makin besar pula hubungannya dengan penilaian kinerja yang berpengaruh terhadap pengembangan karir seseorang.

Menurut Politis (2012) Penjelasan umum adalah bahwa pengalaman kerja menghadapkan individu ke wawasan pribadi dan wawasan unik mengenai masalah pelanggan, pasar yang layak, ketersediaan produk dan sumber daya yang kompetitif yang pada akhirnya mempengaruhi kemampuan mereka untuk mengidentifikasi kekurangan atau inefisiensi dalam cara-cara saat melakukan berbagai hal. Dalam konteks hubungan internasional, penelitian telah menunjukkan bagaimana pengalaman kerja internasional berdampak pada modal karir seseorang (Dickmann and Harris, 2005; Jokinen et al., 2008). Pengalaman kerja dapat dilihat dari total waktu karyawan dalam pekerjaan baik di perusahaan yang sebelumnya maupun perusahaan yang sekarang. Human resources departement tentu akan memperhatikan pengalaman kerja seseorang dalam memberikan suatu jabatan, sehingga jabatan dalam suatu perusahaan dirasa memang sudah tepat bila diduduki oleh karyawan tersebut. 
Pelatihan juga sangat berpengaruh bagi pengembangan karir karyawan karena dari pelatihan yang diberikan oleh perusahaan, karyawan dapat meningkatkan kemampuan dirinya.Salah satu hal yang penting dilakukan dalam perusahaan adalah pelatihan, karena lewat program inilah karyawan bisa lebih mengerti akan tugas dan tanggung jawab yang dipegangnya baik secara perseorangan maupun kelompok (Lestari, 2013). Pelatihan bisa dilakukan dengan metode-metode tertentu sesuai keadaan dan kebutuhan perusahaan serta karyawan. Pelatihan bisa saja berpengaruh signifikan terhadap pengembangan karir karyawan namun bisa juga berpengaruh tidak signifikan karena selain keterampilan individu dalam menerima pelatihan tersebut, materi yang diberikan juga harus tepat sesuai dengan kebutuhan dari karyawan.

Melalui pelatihan yang baik akan membantu mengidentifikasi keunggulan kompetitif strategis dan untuk mengembangkan rencana strategis. Untuk mencapai potensi penuh, pelatihan dan pendidikan akan mendukung daya saing dan akan memungkinkan untuk mempertahankan atau mengembangkan bisnis di masa depan (Peters dan Buhalis, 2004). Ketika karyawan suatu perusahaan diberi pelatihan tentu nilai karyawan tersebut bagi perusahaan akan lebih meningkat, disini diperlukan kebijakan agar tidak kehilangan karyawan yang dibutuhkan oleh perusahaan.

Jika seseorang diberikan peluang guna ikut serta dalam suatu program pelatihan orang tersebut tentu akan mampu melakukan pengembangan karirnya. Dalam arti sempit, program pelatihan akan mampu memberikan pengetahuan serta keterampilan yang akan berguna bagi orang yang mengikutinya guna 
menyelesaikan pekerjaannya (Saputra, 2017). Dalam hal ini pelatihan yang diberikan perusahaan sangat mempengaruhi pengembangan karir karyawan jadi setelah diberikan pelatihan karyawan tersebut seharusnya diberikan tambahan baik tanggung jawab, wewenang maupun tugas sehingga nilai karyawan tersebut juga bertambah.

Bali Masari Villas and SPA adalah perusahaan yang bergerak dalam bidang Villa, dan Spa yang ada di Banjar Gelumpang, Sukawati. Namun walaupun dapat dibilang perusaahan ini cukup besar dibidang Villa, dan Spa di desa Sukawati beberapa aspek belum terasa optimal. Perusahaan belum terlalu memperhatikan tentang pengembangan karir karyawannya sehingga peningkatan karir karyawan belum menjadi prioritas dalam pengembangan SDM di perusahaan ini.

Penelitian kali ini akan dilakukan di Bali Masari Villas and SPA yang merupakan perusahaan yang bergerak di bidang Villa dan SPA .

Tabel 1.

Hasil Prasurvei

\begin{tabular}{cccccc}
\hline Pernyataan & \multicolumn{5}{c}{ Pilihan Jawaban } \\
& STS & TS & CS & S & SS \\
\hline $\mathrm{Y}_{1}$ & & 1 & 4 & & \\
$\mathrm{Y}_{2}$ & & 3 & 2 & & \\
$\mathrm{Y}_{3}$ & & & & 3 & 2 \\
$\mathrm{Y}_{4}$ & & & 2 & 3 & \\
$\mathrm{Y}_{5}$ & & & & 5 \\
$\mathrm{Y}_{6}$ & & & 4 & 1 \\
\hline
\end{tabular}

Sumber : Data diolah, 2017

Dari tabel 1 dapat diketahui bahwa karyawan di Bali Masari Villas and SPA belum merasakan sistem pengembangan karir yang optimal dari perusahaan, dapat dilihat juga di data diatas sebenarnya karyawan di Bali Masari Villas and SPA sangat antusias dalam pengembangan karir namun dukungan perusahaan dinilai 
kurang . Dari uraian diatas dapat diketahui bahwa sistem pengembangan karir di Bali Masari Villas and SPA masih belum optimal. Dari latar belakang masalah tersebut maka judul yang diambil adalah judul Pengaruh penilaian kinerja, pengalaman kerja, dan pelatihan terhadap pengembangan karir di Bali Masari Villas and SPA.

Dari uraian latar belakang diatas maka peneliti mengambil tiga rumusan masalah yaitu : Bagaimana pengaruh penilaian kinerja terhadap pengembangan karir karyawan di Bali Masari Villas and SPA. Bagaimana pengaruh pengalaman kerja terhadap pengembangan karir karyawan di Bali Masari Villas and SPA. Bagaimana pengaruh pelatihan terhadap pengembangan karir karyawan di Bali Masari Villas and SPA.

Berdasarkan rumusan masalah diatas, maka terdapat 3 tujuan penelitian yaitu : Untuk menganalisispengaruh penilaian kinerja terhadap pengembangan karir karyawan di Bali Masari Villas and SPA. Untuk menganalisis pengaruh pengalaman kerja terhadap pengembangan karir karyawan di Bali Masari Villas and SPA. Untuk menganalisis pengaruh pelatihan terhadap pengembangan karir karyawan di Bali Masari Villas and SPA

Manfaat teoritis dalam penelitian ini adalah guna memberikan wawasan serta pengetahuan dalam hal pengaruh penilaian kinerja terhadap pengembangan karir, pengalaman kerja terhadap pengembangan karir, pelatihan terhadap pengembangan karir karyawan di Bali Masari Villas and SPA. Penelitian ini juga diharapkan mampu diteliti lebih lanjut dan mampu dijadikan referensi bagi penulis lain. 
Penelitian ini juga diharapkan mampu membantu manajemen untuk melakukan kebijakan dalam hal penilaian kinerja, pengalaman kerja, dan pelatihan guna meningkatkan pengembangan karir karyawan di Bali Masari Villas and SPA.

\section{TELAAH LITERATUR DAN PENGEMBANGAN HIPOTESIS}

\section{TEORI SUPER}

Teori ini dikembangkan oleh Donald E. Superpada tahun 1953 lalu kembali dikembangkan pada tahun 1957 bersama Jean Pierre Jordaan. Menurut Super et al., (1957) Karakteristik seseorang akan meningkat seiring bertambahnya usia, bersifat multidimensional, berkembang pada berbagai minat individu yang berbeda, dan membantu dalam memprediksi kepuasan kerja, kesuksesan kerja, dan kesuksesan karir. Jadi teori dasarnya adalah bahwa pekerjaan itu konsep diri.

Pada teori super ini terdapat beberapa hal pokok, antara lain : pengembangan karir seseorang dapat dipengaruhi oleh ekonomi, sosio orang tua, tersedianya kesempatan, kepribadian, serta mental orang tersebut. Setiap orang memiliki perbedaan dalam minat dan bakat jadi setiap orang akan memiliki pertimbangan yang berbeda dalam memilih pekerjaannya. Perkembangan seseorang terbagi dalam beberapa tahap, namun pengembangan ini dapat dibantu dengan bantuan uji realitas guna melakukan pengembangan diri. Dalam setiap pekerjaan bisa terbuka bagi setiap orang tergantung bagaimana orang tersebut beradaptasi. Setiap orang akan mengalami proses penuaan. Setiap pekerjaan menghendaki kemampuan, minat serta bakat sehingga banyak pekerjaan bisa terbuka bagi banyak orang.

\section{HIPOTESIS}




\section{Pengaruh Penilaian Kinerja terhadap Pengembangan Karir}

Dari penelitian terdahulu yang telah diteliti oleh Dewi (2015), menemukan tentang pengaruh dari variabel $\mathrm{X}_{1}$ dipenelitian ini yaitu penilaian kinerja yang mempunyai pengaruh positif serta signifikan terhadap variabel pengembangan karir . Penelitian terdahulu lainnya yang dilakukan oleh Rawashdeh (2013), menemukan penilaian kinerja memiliki pengaruh yang postif serta signifikan terhadap pengembangan karir. Di penelitian yang telah dilakukan oleh Jayanti(2013), kembali menemukan hasil yaitu penilaian kinerja berpengaruh positif dan signifikan terhadap pengembangan karir karyawan.

Berdasarkan hasil penelitian sebelumnya, hipotesis yang dapat diajukan dalam penelitian ini adalah:

$\mathrm{H}_{1} \quad$ : Penilaian Kinerja berpengaruh positif dan signifikan terhadap Pengembangan Karir

Hipotesis satu ini memiliki arti ketikapenilaian kinerja yang didapat oleh karyawan semakin baik maka pengembangan karir karyawan tersebut juga akan semakin baik.

\section{Pengaruh Pengalaman Kerja terhadap Pengembangan Karir}

Setelah sebelumnya diteliti oleh Kristola (2009), penelitian ini mengungkapkan hasil pengalaman kerja memiliki berpengaruh positif serta signifikan terhadap pengembangan karir karyawan. Penelitian terdahulu lainnya menemukan hasil yang konsisten pada penelitian Mcllven (2012), mendapatkan pengalaman kerja memberikan pengaruh yang positif dan juga signifikan terhadap 
pengembangan karir karyawan ditempat yang diteliti. Peneliti lainnya yaitu Jayanti (2013) juga menemukan hasil yang sama dengan penelitian dari Kristola (2009) serta Mcllven (2012).

Berdasarkan pemikiran diatas, hipotesis yang dapat diajukan dalam penelitian ini adalah:

$\mathrm{H}_{2} \quad$ : Pengalaman Kerja berpengaruh positif dan signifikan terhadap Pengembangan Karir

Hipotesis dua ini berarti bahwa semakin banyak pengalaman kerja yang dimiliki oleh seorang pegawai maka semakin baik pula pengembangan karir pegawai tersebut.

\section{Pengaruh Pelatihan terhadap Pengembangan Karir}

Setelah sebelumnya diteliti olehSaranani (2015), yang menemukan bahwa pelatihan memiliki pengaruh yang berbanding lurus dengan pengembangan karir. Di penelitian lainnya yang dilakukan oleh Candra (2016) ditemukan hasil bahwa pelatihan memberikan pengaruh positif dan signifikan terhadap pengembangan karir. Dalam penelitian yang dilakukan oleh Muis (2009), mengungkapkan bahwa variabel pelatihan memiliki pengaruh secara positif dan signifikan terhadap variabel pengembangan karir.

Berdasarkan pemikiran diatas, hipotesis yang dapat diajukan dalam penelitian ini adalah: 
$\mathrm{H}_{3} \quad$ : Pelatihan berpengaruh positif dan signifikan terhadap Pengembangan Karir

Hipotesis 3 ini berarti bahwa semakin sering frekuensi pelatihan yang diterima pegawai maka semakin baik pula pengembangan karir pegawai tersebut.

\section{Hasil dan Pembahasan}

\section{Karakteristik Responden}

Dalam pengumpulan data penelitian peneliti menggunakan data primer yang di dapatkan dari kuesioner yang telah diisi oleh respondendi Bali Masari Villas and SPA. Sesuai dengan sampel penelitian jumlah responden adalah 47 orang. Yang diuruaikan berdasarkan karakteristik sebagai berikut.

\section{Jenis kelamin}

\section{Tabel 2.}

Karakteristik Responden Berdasarkan Jenis Kelamin

\begin{tabular}{clcc}
\hline No. & Jenis Kelamin & Jumlah (Orang) & Persentase (\%) \\
\hline 1 & Laki-Laki & 35 & 74,47 \\
2 & Perempuan & 12 & 25,53 \\
\hline & Total & $\mathbf{4 7}$ & $\mathbf{1 0 0}$ \\
\hline
\end{tabular}

Sumber : Data diolah, 2017

Pada tabel 2 dapat dilihat jenis kelamin pada karyawan laki-laki sebanyak 35 orang dan karyawan perempuan sebanyak 12 orang dengan persentase masingmasing sebesar 74,47 persen pada karyawan laki-laki dan 25,53 persen pada karyawan perempuan. Artinya sebagian besar pekerjaan Bali Masari Villas and SPA mempergunakan tenaga laki-laki untuk menyelesaikannya. 
Usia

Tabel 3.

Karakteristik Responden Berdasarkan Usia

\begin{tabular}{cccc}
\hline No & Usia & Jumlah (Orang) & Persentase (\%) \\
\hline 1 & $20-30$ tahun & 11 & 23,40 \\
2 & $31-40$ tahun & 30 & 63,83 \\
3 & $41-50$ tahun & 6 & 12,77 \\
\hline & Total & $\mathbf{4 7}$ & $\mathbf{1 0 0}$
\end{tabular}

Sumber : Data diolah, 2017

Tabel 3 menunjukan bahwa sebagian besar responden berusia di antara 31-40 tahun dengan persentase sebesar 63,38 persen, sedangkan untuk kelompok usia terendah yaitu pada usia 41-50 tahun dengan persentase 12,77 persen. Jadi dapat diartikan bahwa di Bali Masari Villas and SPA diisi oleh karyawan yang sedang dalam masa-masa emas dalam bekerja

\section{Pendidikan terakhir}

Tabel 4.

Karakteristik Responden Berdasarkan Pendidikan Terakhir

\begin{tabular}{llcc}
\hline No. & Pendidikan Terakhir & Jumlah (Orang) & $\begin{array}{c}\text { Persentase } \\
(\mathbf{\%})\end{array}$ \\
\hline $\mathbf{1}$ & SMA / SMK & 12 & 25,53 \\
$\mathbf{2}$ & Diploma 1 (D1) & 15 & 31,91 \\
$\mathbf{3}$ & Diploma 2 (D2) & 13 & 27,66 \\
$\mathbf{4}$ & Diploma 3 (D3) & 3 & 6,38 \\
$\mathbf{5}$ & Sarjana (S.1) & 4 & 8,51 \\
\hline
\end{tabular}

Sumber: Data diolah, 2017

Dapat dilihat ditabel 4 menunjukan bahwa tingkat pendidikan terakhir tidak ada yang terlalu mendominasi. Namun jika dikelompokkan tingkat pendidikan SMA/SMK, Diploma 1 (D1), dan Diploma 2 (D2) adalah tingkat pendidikan terakhir yang paling banyak dimiliki oleh responden yaitu, SMA/SMK sebanyak 12 orang atau 25,53 persen, Diploma 1 (D1) sebanyak 15 orang atau 31,91 persen, dan Diploma 2 (D2) sebanyak 13 orang atau 27,66 persen. Sedangkan kelompok 
pendidikan terakhir yang paling kecil dimiliki oleh responden adalah Diploma 3 (D3) sebanyak 3 orang atau 6,38 persen dan Sarjana (S.1) sebanyak 4 orang atau 8,51 persen.

Lama Bekerja

Tabel 5.

Karakteristik Responden Berdasarkan Lama Bekerja Karyawan

\begin{tabular}{clcc}
\hline No & Masa Bekerja & Jumlah (Orang) & Persentase (\%) \\
\hline 1 & 1-5 tahun & 2 & 4,26 \\
2 & 6-10 tahun & 11 & 23,40 \\
3 & $11-15$ tahun & 34 & 72,34 \\
\hline & Total & $\mathbf{4 7}$ & $\mathbf{1 0 0}$
\end{tabular}

Sumber : Data diolah, 2017

Tabel 5 menunjukan bahwa responden didominasi memiliki pengalaman bekerja 11-15 tahun dimana sebanyak 34 orang atau 72,34 persen, sedangkan pengalaman bekerja 1-5 tahun adalah pengalaman bekerja yang paling sedikit dimiliki oleh karyawan Bali Masari Villas and SPA yaitu sebanyak 2 orang yaitu 4,26 persen. Tabel 5 juga menunjukan bahwa karyawan di Bali Masari Villas and SPA di dominasi oleh karyawan karyawan yang sudah berpengalaman pada bidangnya.

\section{Uji Validitas}

Instrumen dalam suatu penelitian dapat dianggap valid bila skor total bernilai positif dan nilainya lebih dari 0,30 ( $\mathrm{r}>0,3)$. Dalam penelitian ini telah dilakukan uji validitas terhadap setiap butir pernyataan yang digunakan dan berikut adalah hasilnya. 
Tabel 6.

Hasil Uji Validitas

\begin{tabular}{cccc}
\hline Variabel & Indikator & Koefisien Korelasi & Keterangan \\
\hline & $\mathrm{Y}_{1}$ & 0,840 & Valid \\
& $\mathrm{Y}_{2}$ & 0,878 & Valid \\
$\mathrm{Y}$ & $\mathrm{Y}_{3}$ & 0,760 & Valid \\
& $\mathrm{Y}_{4}$ & 0,706 & Valid \\
& $\mathrm{Y}_{5}$ & 0,837 & Valid \\
& $\mathrm{Y}_{6}$ & 0,830 & Valid \\
& $\mathrm{X}_{3.1}$ & 0,773 & Valid \\
& $\mathrm{X}_{3.2}$ & 0,836 & Valid \\
$\mathrm{X}_{3}$ & $\mathrm{X}_{3.3}$ & 0,754 & Valid \\
& $\mathrm{X}_{3.4}$ & 0,781 & Valid \\
& $\mathrm{X}_{2.1}$ & 0,817 & Valid \\
& $\mathrm{X}_{2.2}$ & 0,831 & Valid \\
$\mathrm{X}_{2}$ & $\mathrm{X}_{2.3}$ & 0,839 & Valid \\
& $\mathrm{X}_{2.4}$ & 0,801 & Valid \\
& $\mathrm{X}_{1.1}$ & 0,676 & Valid \\
& $\mathrm{X}_{1.2}$ & 0,704 & Valid \\
& $\mathrm{X}_{1.3}$ & 0,725 & Valid \\
& $\mathrm{X}_{1.4}$ & 0,761 & Valid \\
$\mathrm{X}_{1}$ & $\mathrm{X}_{1.5}$ & 0,766 & Valid \\
& $\mathrm{X}_{1.6}$ & 0,775 & Valid \\
& $\mathrm{X}_{1.7}$ & 0,681 & Valid \\
& $\mathrm{X}_{1.8}$ & 0,776 & Valid \\
\hline
\end{tabular}

Sumber : Data diolah, 2017

Hasil uji validitas pada Tabel 6 menunjukkan penelitian tersebut valid. Selain itu dapat dilihat bahwa pada variabel pengembangan karir yang menunjukan korelasi tertinggi adalah pada item pernyataan $\mathrm{Y}_{2}$ sebesar 0,878 mengenai dukungan dari atasan. Pada variabel pelatihan korelasi tertinggi pada item pernyataan $X_{3.2}$ sebesar 0,836 mengenai materi pelatihan. Pada variabel pengalaman kerja korelasi tertinggi pada item pernyataan $X_{2.3}$ sebesar 0,839 mengenai mampu menyelesaikan tugas tanpa perintah. Pada variabel penilaian kinerja korelasi tertinggi pada item pernyataan $\mathrm{X}_{1.8}$ sebesar 0,776 mengenai dampak penilaian kinerja. 


\section{Uji reliabilitas}

Dalam penelitian ini juga dilakukan uji realiabilitas dimana setiap variabel dalam penelitian ini dapat diketahui apakah sudah reliabel. Suatu variabel dapat dikatakan reliabel jika variabel tersebut mempunyai nilai Alpha Cronbach positif serta lebih dari 0,60.

\section{Tabel 7.}

Hasil Uji Reliabilitas

\begin{tabular}{llrr}
\hline No. & Variabel & Cronbach's Alpha & Keterangan \\
\hline $\mathbf{1}$ & $\mathrm{Y}$ & 0,885 & Reliabel \\
$\mathbf{2}$ & $\mathrm{X}_{3}$ & 0,787 & Reliabel \\
$\mathbf{4}$ & $\mathrm{X}_{2}$ & 0,836 & Reliabel \\
$\mathbf{5}$ & $\mathrm{X}_{1}$ & 0,873 & Reliabel \\
\hline
\end{tabular}

Sumber : Data diolah, 2017

Berdasarkan tabel 7 bahwa semua instrument dipenelitian ini adalah reliabel

\section{Deskripsi Variabel Penelitian}

Dalam penelitian ini digunakan teknik pengumpulan data primer dari kuesioner yang isi kuesioner adalah pernyataan dari setiap variabel dari penelitian ini. Interval dalam kelas yang digunakan adalah 0,80 yang sudah dihitungserta disesuaikan dengan skala yang dipakai yaitu skala 1 sampai 5. Berdasarkan hal tersebut berikut adalah Kriteria pengukuran dalam penelitian ini.

Tabel 8.

Kriteria Pengukuran Deskripsi Variabel Penelitian

\begin{tabular}{ccc}
\hline No. & Skala Pengukuran & Keterangan \\
\hline 1 & $1,00-1,80$ & Sangat Tidak Baik \\
2 & $1,81-2,60$ & Tidak Baik \\
3 & $2,61-3,40$ & Cukup Baik \\
4 & $3,41-4,20$ & Baik \\
5 & $4,21-5,00$ & Sangat Baik \\
\hline
\end{tabular}

Sumber : Data diolah, 2017 


\section{Pengembangan karir}

Tabel 9.

Deskripsi Variabel Pengembangan Karir

\begin{tabular}{ccccccc}
\hline & \multicolumn{6}{c}{ Jawaban } \\
Responden & \multirow{2}{*}{ Ket. } \\
\hline Pernyataan & $\mathbf{1}$ & $\mathbf{2}$ & $\mathbf{3}$ & $\mathbf{4}$ & $\mathbf{5}$ & \\
& 8 & 3 & 9 & 18 & 9 & Cukup Baik \\
$\mathrm{Y}_{1}$ & 0 & 6 & 13 & 17 & 11 & Baik \\
$\mathrm{Y}_{2}$ & 0 & 2 & 14 & 20 & 11 & Baik \\
$\mathrm{Y}_{3}$ & 0 & 3 & 14 & 18 & 12 & Baik \\
$\mathrm{Y}_{4}$ & 0 & 2 & 16 & 16 & 13 & Baik \\
$\mathrm{Y}_{5}$ & 1 & 3 & 13 & 18 & 2 & Baik \\
$\mathrm{Y}_{6}$ & Jumlah Skor Variabel Y \\
& \\
\hline
\end{tabular}

Sumber: Data diolah, 2017

Dapat dilihat pada tabel 9 rata-rata skor yang dimiliki variabel pengembangan karir adalah 3,73 terdapat pada kelas 3,41-4,20 yang dapat diartikan baik. Dari hal tersebut diartikan pengembangan karir di Bali Masari Villas and SPA telah berjalan baik, namun tentu masih bisa ditingkatkan lagi. Dari kuesioner yang telah diisi oleh responden terhadap pernyataan mengenai pengembangan karir nilai rata-rata tertingginya terdapat pada dua pernyataan yaitu sebesar 3,85 pada pernyataan "saya yakin saya berkompeten dibidang pekerjaan saya sekarang” dan pada pernyataan "saya berminat untuk dipromosikan atasan" dan untuk nilai rata-rata terendahnya sebesar 3,36 pada pernyataan "Perusahaan memberikan perlakuan yang adil pada setiap karyawan dalam pengembangan karir". Dari distribusi jawaban responden dapat dilihat bahwa karyawan di Bali Masari Villas and SPA memiliki rasa ingin berkembang yang cukup tinggi. Dengan rasa ingin berkembang yang tinggi maka ini dapat dimanfaatkan untuk meningkatkan pengembangan karir karyawan, dengan memberikan dukungan yang lebih lagi sehingga perkembangan karir karyawan dapat terpenuhi. 


\section{Pelatihan}

Tabel 10.

Deskripsi Variabel Pelatihan

\begin{tabular}{ccccccc}
\hline & \multicolumn{7}{c}{ Jawaban } \\
Pesponden & Ket. \\
Pernyataan & 1 & 2 & 3 & 4 & 5 & Baik \\
& 0 & 6 & 18 & 16 & 7 & Baik \\
$\mathrm{X}_{3.1}$ & 0 & 4 & 11 & 22 & 10 & Baik \\
$\mathrm{X}_{3.2}$ & 0 & 2 & 19 & 18 & 8 & Baik \\
$\mathrm{X}_{3.3}$ & 0 & 3 & 16 & 14 & 14 & 14,83 \\
$\mathrm{X}_{3.4}$ & Jumlah Skor Variabel X \\
\hline
\end{tabular}

Sumber: Data diolah, 2017

Tabel 10 dapat diartikanrata-rata skor yang dimiliki oleh variabel pelatihan adalah 3,71 terdapat pada kelas 3,41 - 4,20 yang dapat diartikan baik. Ini dapat diartikan pengalaman kerja para karyawan di Bali Masari Villas and SPA berada dalam kondisi baik. Distribusi jawaban responden terhadap pelatihan nilai rata-rata tertinggi yaitu sebesar 3,83 pada pernyataan "Perusahaan memberikan prioritas informasi pelatihan kepada karyawan" dan untuk nilai rata-rata terendah adalah sebesar 3,51 pada pernyataan "pelatihan bermanfaat bagi peningkatan kemampuan dan wawasan saya”.

\section{Pengalaman Kerja}

Tabel 11.

Deskripsi Variabel Pengalaman Kerja

\begin{tabular}{ccccccc}
\hline & \multicolumn{7}{c}{ Jawaban } \\
Responden & Ket. \\
\hline $\mathrm{X}_{2.1}$ & 1 & 2 & 3 & 4 & 5 & Baik \\
$\mathrm{X}_{2.2}$ & 1 & 3 & 15 & 19 & 9 & Baik \\
$\mathrm{X}_{2.3}$ & 1 & 5 & 11 & 17 & 13 & Baik \\
$\mathrm{X}_{2.4}$ & 0 & 4 & 17 & 16 & 10 & Baik \\
\hline \multicolumn{8}{c}{ Jumlah Skor Variabel X } \\
\\
Rata-rata SkorVariabel X
\end{tabular}

Sumber: Data diolah, 2017 
Dapat dilihat pada tabel 11 rata-rata skor variabel pengalaman kerja adalah 3,73 terdapat pada kelas 3,41 - 4,20 artinya baik. Hal ini berarti karyawan di Bali Masari Villas and SPA memiliki pengalaman kerja yang tergolong baik. Dari kuesioner yang telah diisi oleh responden dimana nilai rata-rata tertingginya adalah 3,79 pada pernyataan "Berdasarkan pengalaman kerja yang saya miliki, saya bertanggung jawab atas tugas yang yang dibebankan"dan untuk nilai rata-rata terendah sebesar 3,68 terdapat dua, yaitu pada pernyatan "Pengalaman kerja yang saya miliki membuat saya mampu menyelesaikan tugas dengan lancar" dan pada pernyataan "Pengalaman kerja yang saya miliki membuat saya mampu menyelesaikan tugas-tugas yang diberikan tanpa menunggu perintah atasan”.

\section{Penilaian Kinerja}

Tabel 12.

Deskripsi Variabel Penilaian Kinerja

\begin{tabular}{ccccccc}
\hline & \multicolumn{7}{c}{$\begin{array}{c}\text { Jawaban } \\
\text { Responden }\end{array}$} \\
Pernyataan & 1 & 2 & 3 & 4 & 5 & Ket. \\
\hline $\mathrm{X}_{1.1}$ & 2 & 8 & 8 & 19 & 10 & Baik \\
$\mathrm{X}_{1.2}$ & 0 & 4 & 13 & 18 & 12 & Baik \\
$\mathrm{X}_{1.3}$ & 8 & 7 & 12 & 14 & 6 & Cukup Baik \\
$\mathrm{X}_{1.4}$ & 0 & 5 & 15 & 18 & 9 & Baik \\
$\mathrm{X}_{1.5}$ & 2 & 6 & 10 & 17 & 12 & Baik \\
$\mathrm{X}_{1.6}$ & 8 & 11 & 7 & 18 & 3 & Cukup Baik \\
$\mathrm{X}_{1.7}$ & 0 & 4 & 15 & 17 & 11 & Baik \\
$\mathrm{X}_{1.8}$ & 9 & 6 & 12 & 15 & 5 & Cukup Baik \\
\hline \multicolumn{7}{c}{ Jumlah Skor Variabel X } \\
\hline
\end{tabular}

Sumber : Data diolah, 2017

Tabel 12 menunjukan nilai skor rata-rata yang dimiliki oleh variabel penilaian kinerja adalah 3,43 terdapat pada kelas 3,41-4,20 dimana berarti baik. Hal ini berarti penilaian kinerja karyawan di Bali Masari Villas and SPA tergolong pada level yang baik. Dari kuesioner yang telah diisi oleh responden penilaian 
kinerja nilai rata-rata tertingginya sebesar 3,81 pada pernyataan "Penilaian saya cukup akurat Tapi evaluasi kinerja saya tidak lengkap tentang tingkat sebenarnya kinerja saya" dan nilai rata-rata terendah sebesar 2,94 pada pernyataan "Sistem penilaian sering membingungkan saya mengenai Standar kinerja”.

\section{Analisis Regresi Linear Berganda}

Tabel 13.

Hasil Analisis Regresi Linear Berganda

\begin{tabular}{|c|c|c|c|c|c|c|}
\hline \multirow{2}{*}{\multicolumn{2}{|c|}{ Model }} & \multicolumn{2}{|c|}{ Unstandardized Coefficients } & \multicolumn{3}{|l|}{$\begin{array}{l}\text { Standardized } \\
\text { Coefficients }\end{array}$} \\
\hline & & B & Std. Error & Beta & $\mathrm{T}$ & Sig. \\
\hline \multirow[t]{7}{*}{1} & (Constant) & -.411 & 1.599 & & -.257 & .798 \\
\hline & Penilaian Kinerja & .180 & .076 & .264 & 2.377 & .022 \\
\hline & Pengalaman kerja & .539 & .142 & .365 & 3.793 & .000 \\
\hline & Pelatihan & .661 & .147 & .398 & 4.506 & .000 \\
\hline & R Square & & & & & 0.849 \\
\hline & F Statistik & & & & & 80.576 \\
\hline & Signifikansi & & & & & 0.000 \\
\hline
\end{tabular}

Sumber : Data diolah, 2017

Berdasarkan hasil analisis regresi linear berganda seperti yang disajikan

Tabel 4.11, maka persamaan strukturalnya adalah sebagai berikut.

$$
Y=-0,411+0,180 X_{1}+0,539 X_{2}+0,661 X_{3}+e
$$

Dimana :

$$
\begin{array}{ll}
\mathrm{Y} & =\text { Pengembangan Karir } \\
\mathrm{X}_{3} & =\text { Pelatihan } \\
\mathrm{X}_{2} & =\text { Pengalaman Kerja } \\
\mathrm{X}_{1} & =\text { Penilaian Kinerja }
\end{array}
$$

Persamaan regresi linear berganda dapat menunjukan arah serta besarnya pengaruh dari setiap variabel bebas terhadap variabel terikat 
$\mathrm{X}_{1}=+0,180$, menunjukan bahwa penilaian kinerja $\left(\mathrm{X}_{1}\right)$ berpengaruh positif terhadap pengembangan karir (Y) di Bali Masari Villa and SPA.

$\mathrm{X}_{2}=+0,539$, menunjukan bahwa pengalaman kerja $\left(\mathrm{X}_{2}\right)$ berpengaruh positif terhadap pengembangan karir (Y) di Bali Masari Villa and SPA.

$\mathrm{X}_{3}=+0,661$, menunjukan bahwa pelatihan $\left(\mathrm{X}_{3}\right)$ berpengaruh positif terhadap pengembangan karir (Y) di Bali Masari Villa and SPA.

$\mathrm{R}^{2}=+0.849$, yang berarti bahwa sebesar 84,9 persen variabel Pengembangan Karir (Y)dipengaruhi oleh Pelatihan $\left(\mathrm{X}_{3}\right)$, Pengalaman Kerja $\left(\mathrm{X}_{2}\right)$ dan Penilaian Kinerja $\left(\mathrm{X}_{1}\right)$, sedangkan sisanyasebesar 15,1 persen dipengaruhi oleh variabel lainnya di luar model penelitian

\section{Uji Asumsi Klasik}

Hasil dari uji asumsi klasik yang diolah dengan bantuan software SPSS 18.0 disajikan sebagai berikut.

\section{Uji Normalitas}

Tabel 14.

Hasil Uji Normalitas

\begin{tabular}{cc}
\hline & Unstandardized Residual \\
\hline $\mathrm{N}$ & 47 \\
Kolmogorov-Smirnov Z & 0,815 \\
Asymp.Sig.(2-tailed) & 0,520 \\
\hline
\end{tabular}

Sumber : Data diolah, 2017

Dapat dilihat di tabel 14 bahwa Kolmogorov Sminarnov (K-S) memiliki nilai 0,815 dan Asymp. Sig. (2-tailed)memiliki nilai 0,520. Dari hasil uji tersebut berarti model persamaan regresi dipenelitian ini berdistribusi secara normal. 


\section{Uji multikoleniaritas}

Tabel 15.

Hasil Uji Multikoleniaritas

\begin{tabular}{lcc}
\hline \multicolumn{1}{c}{ Variabel } & Tolerance & VIF \\
\hline Penilaian Kinerja $\left(\mathrm{X}_{1}\right)$ & 0,286 & 3,500 \\
Pengalaman Kerja $\left(\mathrm{X}_{2}\right)$ & 0,380 & 2,633 \\
Pelatihan $\left(\mathrm{X}_{3}\right)$ & 0,450 & 2,223 \\
\hline
\end{tabular}

Sumber: Data diolah, 2017

Dari tabel 15 dapat dilihat nilai tolerance dan VIF dari variabel bebas yaitu Penilaian Kinerja, Pengalaman Kerja serta Pelatihan. Nilai yang ditunjukan setelah melakukan uji tersebut adalah tidak ada nilai tolerance variabel lebih besar dari 10\% dan nilai VIF lebih kecil dari 10. Dengan ini dapat diartikan bahwa model dari persamaan regresi dalam penelitian ini bebas dari multikoleniaritas.

\section{Uji heteroskedastisitas}

Tabel 16.

Hasil Uji Heteroskedastisitas

\begin{tabular}{llrrrrr}
\hline Model & \multicolumn{7}{c}{ Unstandardized } & \multicolumn{2}{c}{$\begin{array}{c}\text { Standardized } \\
\text { Coefficients }\end{array}$} \\
& & C & Std. Error & Beta & \multicolumn{1}{c}{ T } & Sig. \\
\hline 1 & (Constant) & 1.521 & 1.079 & & 1.409 & .166 \\
& Penilaian Kinerja & -.055 & .051 & -.298 & -1.071 & .290 \\
& Pengalaman Kerja & -.020 & .096 & -.050 & -.208 & .836 \\
& Pelatihan & .108 & .099 & .241 & 1.086 & .283 \\
\hline
\end{tabular}

Sumber : Data diolah, 2017

Pada tabel 16 dapat dilihat nilai Sig. dari variabel Penilaian Kinerja sebesar 0,290, Pengalaman Kerja sebesar 0,836 , dan Pelatihan sebesar 0,283.Dengan ini nilai Sig. masing masing variabel bebas lebih besar dari 0,05 yang berarti tidak adanya pengaruh antara variabel bebas terhadap absolute residual.

\section{Pengujian Hipotesis}




\section{Uji kelayakan model (Uji F)}

Tabel 17.

Uji ANOVA

\begin{tabular}{llrrrrr}
\hline Model & & Sum of Squares & Df & Mean Square & F & \multicolumn{1}{c}{ Sig. } \\
\hline 1 & Regression & 877.085 & 3 & 292.362 & 80.576 & $.000^{\mathrm{a}}$ \\
& Residual & 156.021 & 43 & 3.628 & & \\
& Total & 1033.106 & 46 & & & \\
\hline Sumber: & Data diolah, 2017 & & & & &
\end{tabular}

Sumber : Data diolah, 2017

Uji ANOVA pada Tabel 17diperoleh nilai sig. 0,000 < 0,05. Kesimpulannya, pada kelompok yang diuji memiliki perbedaan yang signifikan.

\section{Uji parsial (Uji t)}

Kriteria pengujian untuk menjelaskan interpretasi pengaruh antar masingmasing variabel adalah sebagai berikut.

Jika Sig. $\mathrm{t}<0.05$ maka $\mathrm{H}_{0}$ ditolak dan $\mathrm{H}_{1}$ diterima.

Jika Sig. $\mathrm{t}>0.05$ maka $\mathrm{H}_{0}$ diterima dan $\mathrm{H}_{1}$ ditolak.

1) Pengaruh Penilaian Kinerja terhadap Pengembangan Karir.

$\mathrm{H}_{0}$ : Tidak terdapat pengaruh Penilaian Kinerja terhadap Pengembangan Karir.

$$
\left(\beta_{1}=0\right)
$$

$\mathrm{H}_{1}$ : Penilaian Kinerjaberpengaruh positif dan signifikan terhadap Pengembangan Karir $\left(\beta_{1}>0\right)$.

Didasari dari hasil analisis pengaruhPenilaian kinerja terhadap Pengembangan Karir didapatkan nilai Sig. $\mathrm{t}$ sebesar 0,022 dengan nilai koefisien beta 0,264 . Hasil ini mempunyaiartibahwaPenilaian Kinerjaberpengaruh positif dan signifikan terhadap Pengembangan Karir 
2) Pengaruh Pengalaman Kerja terhadap Pengembangan Karir.

$\mathrm{H}_{0}$ : Tidak terdapat pengaruh Pengalaman Kerja terhadap Pengembangan Karir. $\left(\beta_{2}=0\right)$

$\mathrm{H}_{1}$ : Pengalaman Kerja berpengaruh positif dan signifikan terhadap Pengembangan Karir. $\left(\beta_{2}>0\right)$

Didasarkan dari hasil analisis pengaruhPengalaman Kerja terhadap Pengembangan Karir diperoleh nilai Sig. t sebesar 0,000 dengan nilai koefisien beta 0,365. DapatdiartikanbahwaPengalaman Kerja berpengaruh positif dan signifikan terhadap Pengembangan Karir.

3) Pengaruh Pelatihan terhadap Pengembangan Karir.

$\mathrm{H}_{0} \quad$ : Tidak terdapat pengaruh Pelatihan terhadap Pengembangan Karir. $\left(\beta_{3}=0\right)$

$\mathrm{H}_{1}$ : Pelatihan berpengaruh positif dan signifikan terhadapPengembangan Karir. $\left(\beta_{3}>0\right)$

Didasarkan atas hasil dari analisis pengaruh Pelatihan terhadap Pengembangan Karirdiperoleh nilai Sig. t sebesar 0,000 dengan nilai koefisien beta 0,398. Hasilanalisis ini berartibahwa Pelatihanberpengaruh positif dan signifikan terhadap Pengembangan Karir.

\section{Pembahasan Hasil Penelitian}

\section{Pengaruh penilaian kinerja terhadap pengembangan karir}


Menurut hasil penelitian ini maka dapat dinyatakan penilaian kinerja mempunyai pengaruh yang positif serta signifikan terhadap pengembangan karir. Hal ini dpat diartikan jika kinerja dari seorang pegawai dinilai baik maka pegawai tersebut karirnya akan berkembang di Bali Masari Villas and SPA. Jadi penilaian kinerja dijadikan acuan dalam melakukan pengembangan karir karyawan sesuai dari kebutuhan, minat dan bakat karyawan tersebut. Jika dibandingkan dengan penelitian terdahulu yang terdapat pada hipotesis maka penelitian ini telah berbanding lurus dengan penelitian dari Dewi (2015) Rawashdeh (2013), Jayanti(2013).

\section{Pengaruh pengalaman kerja terhadap pengembangan karir}

Dari penelitian ini hasil yang diperoleh adalah pengalaman kerja memiliki pengaruh yang positif serta signifikan terhadap pengembangan karir. Disini dapat diartikan bahwa pengalaman kerja berbanding lurus dengan pengembangan karir, sehingga jika seorang karyawan memiliki pengalaman kerja yang banyak pengembangan karir karyawan tersebut di Bali Masari Villas and SPA akan meningkat. Perusahaan harus lebih berani lagi dalam memberikan pengalaman terhadap karyawannya guna membantu karir dari karyawan tersebut. Jika dibandingkan dengan penelitian sebelumnya maka hasil ini berbanding lurus dengan penelitian Kristola (2009), Mcllven (2012), Jayanti (2013).

\section{Pengaruh pelatihan terhadap pengembangan karir}

Penelitian ini mengungkapkan pelatihan memiliki pengaruh positif dan signifikan terhadap pengembangan karir. Hal ini berarti jika Bali Masari Villas and 
SPA ingin memberikan pengembangan karir terhadap karyawannya maka bisa dilakukan dengan memberikan pelatihan terhadap karyawan tersebut, karena pelatihan dan pengembangan karir adalah variabel yang berbanding lurus. Hasil dari penelitian ini juga berbanding lurus dengan yang telah diungkapkan oleh Saranani (2015), Candra (2016), Muis (2009).

\section{SIMPULAN DAN SARAN}

Simpulan dari analisis serta pembahasan yang telah dilakukan dalam penelitian ini adalah. Penilaian kinerja $\left(\mathrm{X}_{1}\right)$ memiliki pengaruh secara positif dan juga signifikan terhadap variabel pengembangan karir (Y). Hal ini memiliki arti bahwa penilaian kinerja memiliki pengaruh yang berbanding lurus dengan pengembangan karir. Pengalaman kerja $\left(\mathrm{X}_{2}\right)$ memiliki pengaruh secara positif dan juga signifikan terhadap variabel pengembangan karir (Y). Hal ini memiliki arti bahwa pengalaman kerja memiliki pengaruh yang berbanding lurus dengan pengembangan karir. Pelatihan $\left(\mathrm{X}_{3}\right)$ memiliki pengaruh secara positif dan juga signifikan terhadap variabel pengembangan karir (Y). Hal ini memiliki arti bahwa pelatihan memiliki pengaruh yang berbanding lurus dengan pengembangan karir.

Sumber daya manusia yang minim pengalaman diharapkan untuk lebih mengikuti pelatihan agar tidak kesulitan dalam menjalankan tugas yang diberikan.SDM akan melakukan pengembangan karir perlu memiliki melampaui standar kinerja yang ditentukan agar penilaian kinerjanya terlihat baik.Sumber daya manusia yang sudah bekerja lama di perusahaan jangan pernah merasa cukup belajar sehingga tidak tertinggal oleh teknologi.Bagi peneliti yang mempunyai 
masalah yang sama disarankan untuk melakukan kajian terhadap referensi yang lebih luas dan juga mampu mempertimbangkan faktor lain yang mempengaruhi variabel tersebut.

Pengembangan Karir adalah serangkaian proses yang dilakukan dalam hidup guna meningkatkan kemampuan individu. Namun dalam kepentingannya pengembangan karir setiap karyawan akan berbeda sesuai prioritas yang berbeda datang ke permukaan.Pelatihan adalah sarana untuk mengembangkan pengetahuan, keterampilan dan sikap individu yang berkaitan dengan pekerjaan. Pelatihan dinyatakan berhasil apabila membawa dampak positif pada pengembangan keterampilan karyawan.Pengalaman kerja adalah suatu dasar atau acuan seseorang dalam mengidentifikasi kekurangan dan inefisiensi dalam melakukan pekerjaannya. Seseorang bisa mendapatkan pengalaman kerja apabila lingkungan yang stabil dan transparan sehingga orang tersebut bisa dengan mudah berkembang dan belajar.Penilaian kinerja adalah sistem SDM yang resmi guna menyediakan evaluasi kerja yang dimiliki oleh setiap karyawan agar karyawan menjadi lebih baik lagi. Penilaian kinerja yang transparan dan objektif akan mampu mengidentifikasi kinerja karyawan, sehingga koreksi dapat diberikan atas kinerja karyawan yang dianggap belum optimal.

\section{REFERENSI}

Ardianta, I Wayan. 2014. Pengaruh Diklat, Kepemimpinan dan Penerapan Budaya Organisasi Terhadap Kinerja Karyawan Pada Hotel Bali Dwipa Legian Kuta. E-Jurnal Manajemen Universitas Udayana, 3 (9) : 2685-2697. 
Candra, Ni Nyoman Witya. 2016. Pengaruh Pengalaman Kerja, Pelatihan Terhadap Pengembangan Karir Di PT. PLN (Persero) Distribusi Bali.E-Jurnal Manajemen Unud, 5 (9) : 5839-5867.

Crowley-Henry, Marian. 2012. Re-conceptualizing the career development of self initiated expatriates: rivers not ladders. Journal of Management Development, 31 (2): 130-141.

Dessler, Gary. 2008. Human Resource Management. Florida International University.

Dewi, I.A Putu Kartika. 2015. Pengaruh Penilaian Kinerja dan Pengalaman Kerja Terhadap Pengembangan Karir Pada PT Bali Biasa Indah Koleksi Kuta Bali. E-Jurnal Manajemen Unud, 4(7) : 1918-1933.

Dickmann, Michael., and Harris, Hilary. 2005.Developing career capital for global careers: the role of international assignments.Journal of World Business, 40(4) : 399-408.

Dokko, Ginna., Steffanie L. Wilk., And Nancy P. Rothbard.2008. Unpacking Prior Experience How Career History Affects Performance. Articles In Advance. 6 (10): 1-18.

Donald E. Super., and Jean Pierre Jordaan. 1973. Career development theory.British Journal of Guidance \& Counselling, 1 (1) : 3-16.

Grote, Dick. 2002. The performance appraisal question and answer book: survival guide for manager. New York : AMACOM.

Jayanti, Anak Agung Sagung Siskani. 2013. Pengaruh Prestasi Kerja, Pendidikan, Pengalaman Kerja, Pengenalan Dan Kesempatan Untuk Tumbuh Terhadap Pengembangan Karir Pegawai Negeri Sipil Pada Kantor Dinas Ketentraman Ketertiban Dan Satuan Polisi Pamong Praja Kota Denpasar. E - Jurnal Manajemen Universitas Udayana. 9 (2) : 333-367.

Jokinen, Tiina., Brewster, Chris., and Suutari, Vesa. 2008.Career capital during international work experiences: contrasting self-initiated expatriate experiences and assigned expatriation.International Journal of Human Resource Management, 19 (6) : 979-90.

Kaseger, Regina Gledy. 2013. Pengembangan Karir Dan Self - Efficacy Terhadap Kinerja Karyawan Pada PT. Matahari Departement Store Manado Town Square. Jurnal EMBA. 4 (1) : 342-350.

Kristola, Dio. 2009. Pengaruh Diklat dan Pengalaman Kerja Terhadap Prestasi Kerja Serta Dampaknya Terhadap Pengembangan Karir Pegawai di Balai Karantina Pertanian Kelas1 Denpasar. E-Jurnal Manajemen Universitas Udayana, 8(10) : 42-45. 
Kumara, I Wayan Sutya Edi. 2016. Pengaruh Pelatihan Terhadap Kinerja Karyawan Dengan Mediasi Kepemimpinan Pada Hotel Satriya Cottages Kuta-Bali. E - Jurnal Manajemen Universitas Udayana, 5 (3) : 1399-1428.

Lestari, Putu Ayu. 2013. Pengaruh Pelatihan Kerja, Lingkungan Kerja Fisik serta Motivasi terhadap Produktivitas Kerja Pegawai pada PT. Taspen (Persero) Kantor Cabang Denpasar. E - Jurnal Manajemen Universitas Udayana. 2 (9) : 1071-1084.

Mahony, Douglas M., Malayka Klimchak., And Daniel L. Morrel. 2012. The Portability Of Career-Long Work Experience Propensity To Trust As A Substitute For Valuable Work Experience. Emerald Group Publishing Limited, 17(7) : 606-625.

Mcllveen, Peter. 2012. A Longitudinal Study of The Experience of A Career Development Program For Rural School Students. Career Education and Higher Education. 3(1) : 11-14.

Muis, Mahlia. 2009. Analisis Faktor-faktor yang Mempengaruhi Pengembangan Karir Karyawan Perbankan di Kota Makassar. Jurnal Aplikasi Manajemen, 7(9) : 629-634.

Peters, Mike., And Dimitrios, Buhalis. 2004. Family hotel businesses: Strategic planning and the need for education and training. 'Education and Training' Special Edition, 1 (1) : 1-21.

Politis, Jonas., and Gabrielsson, Diamanto. 2012.Work experience and the generation of new business ideas among entrepreneurs.International Journal of Entrepreneurial Behavior \& Research, 18 (1) : 48 -74.

Prowse, Peter., and Prowse, Julie. 2009. The dilemma of performance appraisal.Measuring Business Excellence, 13 (4) : 69 - 77.

Rawashdeh, Abas Salem. 2013. Impact of Human Resource System and Practices on Attitude Toward Carrer Development Program in The Banking Sector $\mathrm{f}$ Jordan. European Scientific Journal, 9(19) : 236-252.

Riandiyani, Mirza. 2013. Pengaruh Kompensasi Intrinsik Dan Kompensasi Ekstrinsik Serta Pelatihan Kerja Kerja Terhadap Kinerja Karyawan. E Jurnal Manajemen Universitas Udayana, 2 (12) : 1512-1526.

Rivai, Veithzal. 2011. Manajemen Sumber Daya Manusia Untuk Perusahaan. Jakarta: PT. Raja Grafindo Persada.

Saleem, Sharjeel., and Saba, Amin. 2013. The Impact of Organizational Support for Career Development and Supervisory Suppoert on Employee Performance : An Emperical Study From Pakistani Academic Sector. Europen Journal of Business and Management. 5 (5) : 194-207. 
Saputra, I Dewa Gede Agus. 2017. Pengaruh Promosi Jabatan, Pelatihan dan Lingkungan Kerja Terhadap Kepuasan Kerja Karyawan. E - Jurnal Manajemen Universitas Udayana, 6 (2) : 1030-1054.

Saranani, Fajar. 2015. Effect Of Education And Training To Performance Mediated Career Development Inspectorate City Employees Kendari. The International Journal Of Engineering And Science (IJES) 4 (3) : 28-36.

Sari, Eliana., Joni Sinulingga. 2011. Pengaruh Pengembangan Karir Dan Kompensasi Terhadap Motivasi Karyawan. Jurnal Ilmiah Penelitian Manajemen Manajerial, 2(1) : 431-440.

Steven, H Appelbaum., Michel Roy., and Terry Gilliland. 2011. Globalization of performance appraisals: theory and applications.Management Decision, 49 (4) : 570-585.

Wang, Y.-F., Chiang, M.-H., and Lee, Y.-J. 2014. The relationships amongst the intern anxiety, internship outcomes, and career commitment of hospitality college students. Journal of Hospitality, Leisure, Sport and Tourism Education, 15 (4) : 86-93. 